\title{
Analysis of the ability to understand mathematical concepts in class VII quadrilateral material.
}

\author{
Analisis Kemampuan Pemahaman Konsep Matematika Pada \\ Materi Segiempat Kelas VII
}

\begin{tabular}{l}
\hline Author \\
\hline Lambok Simamora \\
Universitas Indraprasta PGRI \\
Jl. Raya Tengah No. 80 \\
simamoralambok@gmail.com \\
Roida Eva Flora Siagian \\
Universitas Indraprasta PGRI \\
Jl. Raya Tengah No. 80 \\
Roida.siagian20@ gmail.com \\
Liza Cahyani \\
Universitas Indraprasta PGRI \\
Jl. Raya Tengah No. 80 \\
lizacahyani.lc@gmail.com
\end{tabular}

\section{Duconomics Sci-meet}

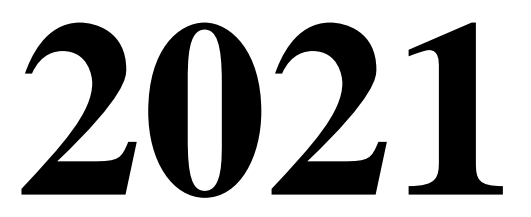

VOLUME 1

JULI

Page

20-30

\section{DOI}

10.37010/duconomics.v1.5448

\begin{abstract}
Research conducted at SMP Negeri 39 Bekasi aims to determine:

The ability to understand mathematical concepts of students on quadrilateral material with an indicator of the ability to understand mathematical concepts used is killpatrick. The type of research used is descriptive qualitative. This research was conducted on 35

students, the method of taking the subject in this study was using purposive sampling, the subjects were taken as many as 9 students,

namely 3 high-ability students, 3 medium-capable students, and 3 low-ability students. The data collection technique was carried out

with test instruments that had been empirically validated and the results of interviews with the subject. The instrument used was in the form of 2 items on the ability of students to understand mathematical

concepts on the rectangular material accompanied by interviews with students. The results of the study concluded that: The ability to

understand mathematical concepts of class VII students of SMP

Negeri 39 Bekasi for the 2019/2020 academic year was in the medium category
\end{abstract}

Keywords

Analysis, concept understanding, rectangular

Abstrak

Penelitian yang dilaksanakan di SMP Negeri 39 Bekasi memiliki tujuan untuk mengetahui: Kemampuan pemahaman konsep matematika peserta didik pada materi segiempat dengan indikator kemampuan pemahaman konsep matematika yang digunakan adalah killpatrick. Adapun jenis penelitian yang digunakan adalah deskriptif

kualitatif. Penelitian ini dilakukan kepada 35 peserta didik, cara pengambilan subjek dalam penelitian ini menggunakan purposive sampling, subjek yang diambil sebanyak 9 peserta didik, yaitu 3 peserta didik yang berkemampuan tinggi, 3 peserta didik yang

berkemampuan sedang, dan 3 peserta didik yang berkemampuan rendah. Teknik pengumpulan data dilakukan dengan instrumen tes yang sudah divalidasi secara empiris dan hasil wawancara kepada subjek. Instrumen yang digunakan berupa 2 butir soal kemampuan pemahaman konsep matematika peserta didik pada materi segiempat disertai wawancara kepada peserta didik. Hasil penelitian menyimpulkan bahwa: Kemampuan pemahaman konsep matematika peserta didik kelas VII SMP Negeri 39 Bekasi Tahun Ajaran 2019/2020 tergolong dalam kategori sedang.

Kata kunci

Analisis, pemahaman konsep, segiempat 


\section{PENDAHULUAN}

Pendidikan adalah suatu investasi terhadap sumber daya manusia untuk mengembangkan potensi dan kemampuan yang dimilikinya. Dalam arti luas, pendidikan dapat diartikan sebagai suatu proses dengan metode-metode tertentu sehingga orang memperoleh pengetahuan, pemahaman, dan cara bertingkah laku yang sesuai dengan kebutuhan.

Hal ini sesuai dengan tujuan pendidikan nasional yang tercantum dalam Undangundang Republik Indonesia Nomor 20 tahun 2003 tentang Sistem Pendidikan Nasional Bab 1 ayat 2. Dalam pencapaian tujuan pendidikan nasional Indonesia, terdapat sejumlah mata pelajaran pokok dan pendukung. Sesuai dengan Peraturan Menteri Pendidikan Nasional No. 22 Tahun 2006 tentang Standar Isi Satuan Pendidikan pasal 1 ayat 1 yang menyebutkan bahwa salah satu diantara mata pelajaran pokok di sekolah yang diajarkan kepada siswa adalah mata pelajaran matematika. Hal tersebut menyebabkan matematika menjadi mata pelajaran yang penting untuk dikuasai siswa.

Pemahaman Konsep merupakan buah pikiran seseorang atau sekelompok orang yang dinyatakan dalam definisi sehingga melahirkan produk pengetahuan, meliputi prinsip hukum dan teori (Syaiful Sagala, 2010:71). Dalam upaya untuk mengoptimalisasi pemahaman konsep pada siswa adalah siswa harus berani mengungkapkan pendapatnya tentang materi yang disampaikan guru atau temannya.

Berdasarkan hasil wawancara yang dilakukan oleh peneliti di SMP Negeri Wilayah Kecamatan Jatiasih, terungkap masalah yang berhubungan dengan pembelajaran matematika, terutama dalam hal pemahaman konsep matematika. Guru yang bersangkutan sudah pernah menggunakan berbagai macam metode pembelajaran dalam melaksanakan proses pembelajaran matematika, seperti menggunakan pembelajaran langsung, metode ceramah, diskusi, metode kelompok dan lainnya. Namun usaha guru tersebut belum mampu mencapai tujuan yang diharapkan yaitu nilai matematika yang diperoleh siswa kelas VII belum mencapai Kriteria Ketuntasan Minimum (KKM), KKM matematika kelas VII adalah 65. Peneliti menyadari bahwa siswa masih kurang memahami konsep matematika khususnya pada materi bangun ruang segiempat. Sehingga perlu dilakukan Analisis Pemahaman Konsep Matematika Pada Materi Segiempat kelas VII.

Rumusan Masalah pada penelitian ini yaitu bagaimana kemampuan pemahaman konsep matematika siswa pada materi segiempat kelas VII di SMP Negeri 39 Kota Bekasi sehingga tujuan dilakukannya penelitian ini untuk menganalisis kemampuan pemahaman konsep matematika siswa pada materi segiempat kelas VII di SMP Negeri 39 Kota Bekasi. Ranah kognitif berhubungan dengan konteks intelektual yang berhubungan dengan cara dan kemampuan berfikir.

Ranah kognitif berhubungan dengan konteks intelektual yang berhubungan dengan cara dan kemampuan berfikir. Ranah kognitif memiliki beberapa aspek pada tingkatannya, tingkat pertama memiliki dua aspek dasar yaitu mengingat dan memahami, tingkat selanjutnya tahap mengaplikasikan ada empat aspek, aspek tersebut yaitu menerapkan, menganalisis, mengevaluasi, dan menciptakan.

Pemahaman konsep diharap dapat mengembangkan cara berpikir peserta didik menjadi lebih baik dan terstruktur. Pemahaman konsep yang dimiliki peserta didik dalam pembelajaran matematika dapat dilihat dari beberapa aspek dalam proses pemahaman yang dijalani oleh peserta didik. Indikator pemahaman konsep merupakan pedoman untuk melihat baik atau tidaknya pemahaman konsep yang dimiliki oleh siswa.

Indikator pemahaman konsep matematika yang digunakan oleh peneliti adalah indikator menurut Kilpatrick dan Findell (2002) yaitu: (1) Menyatakan ulang sebuah konsep 


\section{2

yang telah dipelajari; (2) Memberikan contoh dari konsep yang telah dipelajari; (3)

Mengaitkan berba-gai konsep yang telah dipelajari.

Pemahaman konsep berkaitan erat terhadap proses pembelajaran yang dilakukan oleh siswa, bukan hanya selama proses pembelajaran di kelas tetapi juga luar sekolah. Ada beberapa faktor sehingga proses pemahaman konsep pun juga tidak akan mereka kuasi sepenuhnya. Menurut Sari (2013:4) Adapun faktor yang menyebabkan siswa mengalami kesulitan dalam memahami konsep matematika disebabkan oleh hal-hal seperti: (1) Siswa tidak bisa menangkap konsep dengan benar dan tidak mengerti lambang yang digunakan dalam bahasa matematika serta menggunakannya; (2) Siswa tidak dapat memahami asal-usul suatu rumus, artinya siswa tahu apa rumus dan teorema namun tidak mengetahui bagaimana rumus itu digunakan; (3) Kurangnya pengetahuan siswa yang pada akhirnya menghambat dalam memecahkan masalah matematika, sementara materi terus berlanjut sampai selesai.

Bangun datar segiempat merupakan salah satu pokok bahasan yang diberikan pada kelas VII semester genap. Ada 6 sub pokok bahasan yang diuraikan dalam pokok bahasan bangun datar segiempat di kelas VII SMP yaitu sub pokok bahasan persegi-panjang, persegi, jajar-genjang, belah ketupat, layang-layang, dan trapesium.

Siswa mempelajari pokok bahasan bangun datar segiempat ini dengan tujuan yaitu yang pertama agar siswa mampu memahami dan menentukan keliling dan luas dari masingmasing bangun datar segiempat tersebut. Misalnya pada sub pokok bahasan persegi- panjang, siswa diharapkan mampu memahami pengertian keliling dan luas persegi-panjang, dan sama halnya dengan bangun datar lainnya.

Tujuan yang kedua dalam mempelajari pokok bahasan bangun datar segiempat, siswa diharapkan mampu menerapkan bangun datar segiempat dalam kehidupan sehari-hari. Misalnya Pak Sukardi akan memanam padi di sawahnya, untuk memperkirakan berapa banyak bibit yang dibutuhkan maka Pak Sukardi harus mengetahui luas sawah tersebut, sedangkan untuk mengetahui luas sawah, Pak Sukardi harus mengukur berapa panjang dan lebar sawah tersebut. Pembelajaran penerapan bangun datar segiempat pada kehidupan seharihari dimatematika dituangkan dalam bentuk soal cerita.

Ada beberapa perbandingan penelitian terdahulu yang dilakukan beberapa peneliti dengan penelitian yang sekarang sebagai berikut :

Tabel 1. Kisi-Kisi Soal Pemahaman Konsep Matematika 
Duconomics Sci-meet Vol. 1

Juli, 2021

https://www.doi.org/10.37010/duconomics.v1

\section{METODE}

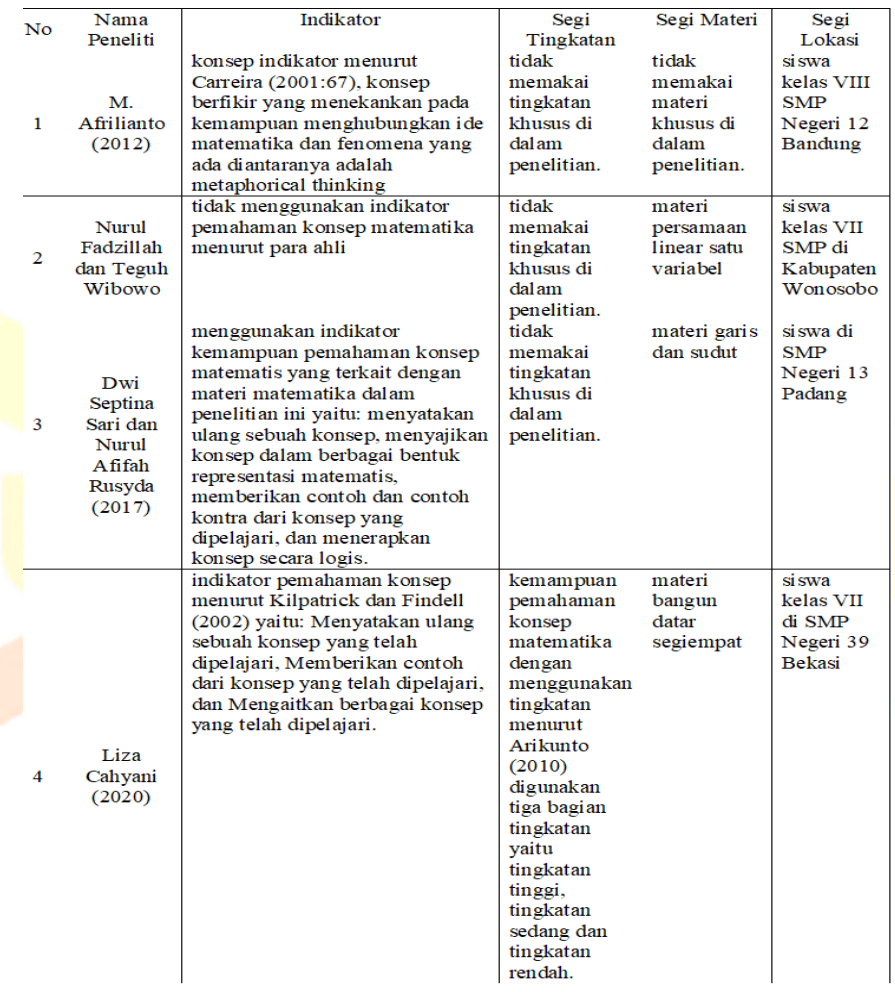

Penelitian yang dilakukan dalam penelitian ini oleh peneliti bersifat kualitatif, di mana pendapat kualitatif di cetuskan oleh Sugiono (2010:17), menulis bahwa Penelitian kualitatif memandang objek sebagai sesuatu yang dinamis, hasil pemikiran dari interprestasi terhadap gejala yang diamati, serta utuh (holistic) karena setiapspek dari obyek itu mempunyai satu kesatuan yang tidak dapat dipisahkan.

Penelitian ini lebih menekankan pada makna yang akan diambil dari hasil penelitian yang dilakukan. Metode Deskriptif yaitu suatu metode yang bertujuan untuk membuat deskriptisi, gambaran atau lukisan secara sistematis, faktual, akurat mengenai sifat-sifat populasi atau daerah tertentu". Pendapat tersebut sejalan dengan pendapat dari F.L.Whitney dalam Nasir 2003:54,"Metode deskriptif adalah pencarian fakta dengan iterprestasi yang tepat".

Penelitian diambil di kelas VII. G sebanyak 35 siswa dari tujuh kelas (VII A, VII B, VII C, VII D, VII E, VII F, VII G) yang ada. Pengambilan kelas yang menjadi subjek penelitian ini didasari pada beberapa pertimbangan bahwa kelas VII G memiliki nilai rata-rata matematika yang masih di bawah Kriteria Ketuntasan Minimum (KKM) jika dibandingkan dengan kelas lainnya. Sebelum penelitian, terlebih dahulu dilakukan tes uji instrument pemahaman konsep matematika kepada para ahli yang bukan merupakan subjek penelitian agar dapat mengetahui apakah soal tersebut dapat digunakan untuk penelitian atau tidak. Kemudian setelah didapatkan hasil dari uji para ahli dan direvisi test soal diujikan kepada kelas VII G selaku subjek penelitian. Peserta didik dipilih berdasarkan analisis dari hasil tes yang dibuat peneliti.

Dari hasil tes tersebut dikelompokkan menjadi tiga kelompok, yaitu peserta didik dengan kemampuan matematika tinggi, peserta didik dengan kemampuan matematika sedang, dan peserta didik dengan kemampuan matematika rendah. Masing-masing kelompok dipilih tiga peserta didik sebagai perwakilan kelompok, sehingga ditetapkan 9 peserta didik sebagai subjek penelitian dalam pembahasan. Kemudian nantinya akan dilakukan pengecekan dengan hasil wawancara terhadap subjek penelitian, teknik pengecekan ini disebut juga teknik triangulasi. 
Sumber dan jenis data yang diambil dalam penelitian ini adalah data yang diperoleh dari hasil pemberian soal uraian sebanyak dua soal. Setelah memberi dua soal uraian yang mencangkup tiga indikator dari kemampuan pemahaman konsep matematika ke para ahli, dalam hal ini validasi soal peneliti melibatkan dua guru bidang studi matematika di SMP Negeri 39 Kota Bekasi dan satu dosen pendidikan matematika untuk di test uji instrument apakah soal tersebut layak digunakan atau tidak. Selanjutnya dengan menetapkan kelas VII.G yang dijadikan sampel dan diberikan tes kemampuan pemahaman konsep matematika, dari hasil validasi para ahli dalam rangka memilih siswa untuk dijadikan subjek penelitian berdasarkan kemampuan matematika siswa. Sehingga terpilih sembilan siswa yang terdiri tiga siswa berkemampuan tinggi, tiga siswa berkemampuan sedang dan tiga siswa berkemampuan rendah.

Teknik Pengumpulan data yang dilakukan dalam penelitian analisis kemampuan pemahaman konsep matematika pada materi segiempat kelas VII ini adalah melalui observasi, wawancara dan dokumentasi.

Tujuan analisis adalah memfasilitasi interpretasi data dan membuat data bermakna. Semua teknik bertujuan memecahkan data menjadi terurai, mengkonfigurasikan data dan mengatur data yang memungkinkan peneliti untuk melihat sesuatu yang baru atau melihat yang spesifik. Adapun analisis data yang dilakukan dalam penelitian ini meliputi reduksi data, penyajian data dan menarik kesimpulan.

\section{HASIL DAN PEMBAHASAN}

\section{Hasil}

Penelitian ini dilaksanakan di SMP Negeri 39 Bekasi pada kelas VII G sebagai subjek penelitian. Selanjutnya sebelum penelitian, terlebih dahulu dilakukan validasi soal tes kemampuan pemahaman konsep matematika kepada para ahli yang terdiri dari satu dosen pendidikan matematika di Universitas Indraprasta PGRI dan dua guru mata pelajaran matematika di SMP Negeri 39 Bekasi yang bukan merupakan subjek penelitian agar dapat mengetahui apakah soal tersebut dapat digunakan untuk penelitian atau tidak. Setelah mendapatkan soal yang valid, kemudian soal diujikan kepada kelas VII G selaku subjek penelitian. Subjek dalam penelitian pendahuluan ini di kelas VII G sebanyak 35 siswa. Berikut ini adalah kisi-kisi indikator test pemahaman konsep matematika yang telah di uji para ahli dan sudah direvisi peneliti:

Tabel 2. Kisi-Kisi Soal Pemahaman Konsep Matematika 
Duconomics Sci-meet Vol. 1

Juli, 2021

https://www.doi.org/10.37010/duconomics.v1

\begin{tabular}{|c|c|c|c|c|}
\hline $\begin{array}{c}\text { Kompetensi } \\
\text { Dasar }\end{array}$ & $\begin{array}{l}\text { Indikator } \\
\text { Kemampuan } \\
\text { Pemahaman } \\
\text { Konsep }\end{array}$ & $\begin{array}{c}\text { Indikator } \\
\text { Materi } \\
\text { Pemahaman } \\
\text { Konsep } \\
\text { Matematika }\end{array}$ & $\begin{array}{c}\text { Materi Soal sesuai Indikator } \\
\text { Kemampuan Pemahaman } \\
\text { Konsep Matematika }\end{array}$ & $\begin{array}{l}\text { No } \\
\text { Soal }\end{array}$ \\
\hline $\begin{array}{l}\text { Menyel esaikan } \\
\text { masalah yang } \\
\text { berkaitan } \\
\text { dengan konsep } \\
\text { bangun datar } \\
\text { segiempat } \\
\text { (persegi, } \\
\text { persegi } \\
\text { panjang, belah } \\
\text { ketupat, } \\
\text { jajargenjang, } \\
\text { trapesium, dan } \\
\text { layang-layang) }\end{array}$ & $\begin{array}{l}\text { Menyatakan } \\
\text { ulang konsep } \\
\text { yang telah } \\
\text { dipelajari }\end{array}$ & $\begin{array}{l}\text { Menentukan } \\
\text { contoh benda } \\
\text { dan } \\
\text { mengambarkan } \\
\text { serta } \\
\text { menentukan } \\
\text { diagonal datar } \\
\text { bangun segiempat. }\end{array}$ & 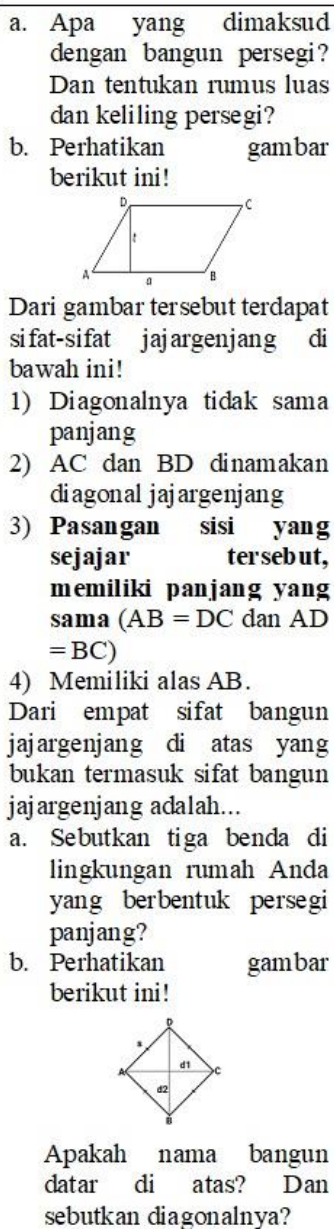 & $\begin{array}{l}1 \mathrm{a} \\
\text { dan } \\
2 \mathrm{a}\end{array}$ \\
\hline
\end{tabular}

Dari hasil tes tersebut dikelompokkan menjadi tiga kelompok, yaitu peserta didik dengan kemampuan matematika tinggi, peserta didik dengan kemampuan matematika sedang, dan peserta didik dengan kemampuan matematika rendah. Masing-masing kelompok dipilih tiga peserta didik sebagai perwakilan kelompok, sehingga ditetapkan sembilan peserta didik sebagai subjek penelitian. Kemudian nantinya akan dilakukan pengecekan dengan hasil wawancara terhadap subjek penelitian, teknik pengecekan ini disebut juga teknik triangulasi. Data yang digunakan dalam penelitian ini adalah hasil tes kemampuan pemahaman konsep matematika pada materi bangun datar segiempat dan hasil wawancara kepada peserta didik, data-data yang diperoleh kemudian dianalisa untuk menunjukan tingkat kemampuan pemahaman konsep matematika melalui tes berbentuk uraian.

Adapun data hasil penelitian yaitu daftar nilai kemampuan pemahaman konsep matematika pada materi bangun datar segiempat di kelas $7 \mathrm{G}$ diperoleh hasil sebagai berikut:

Tabel 3. Daftar Nilai Uji Instrument Kemampuan Pemahaman Konsep Matematika 


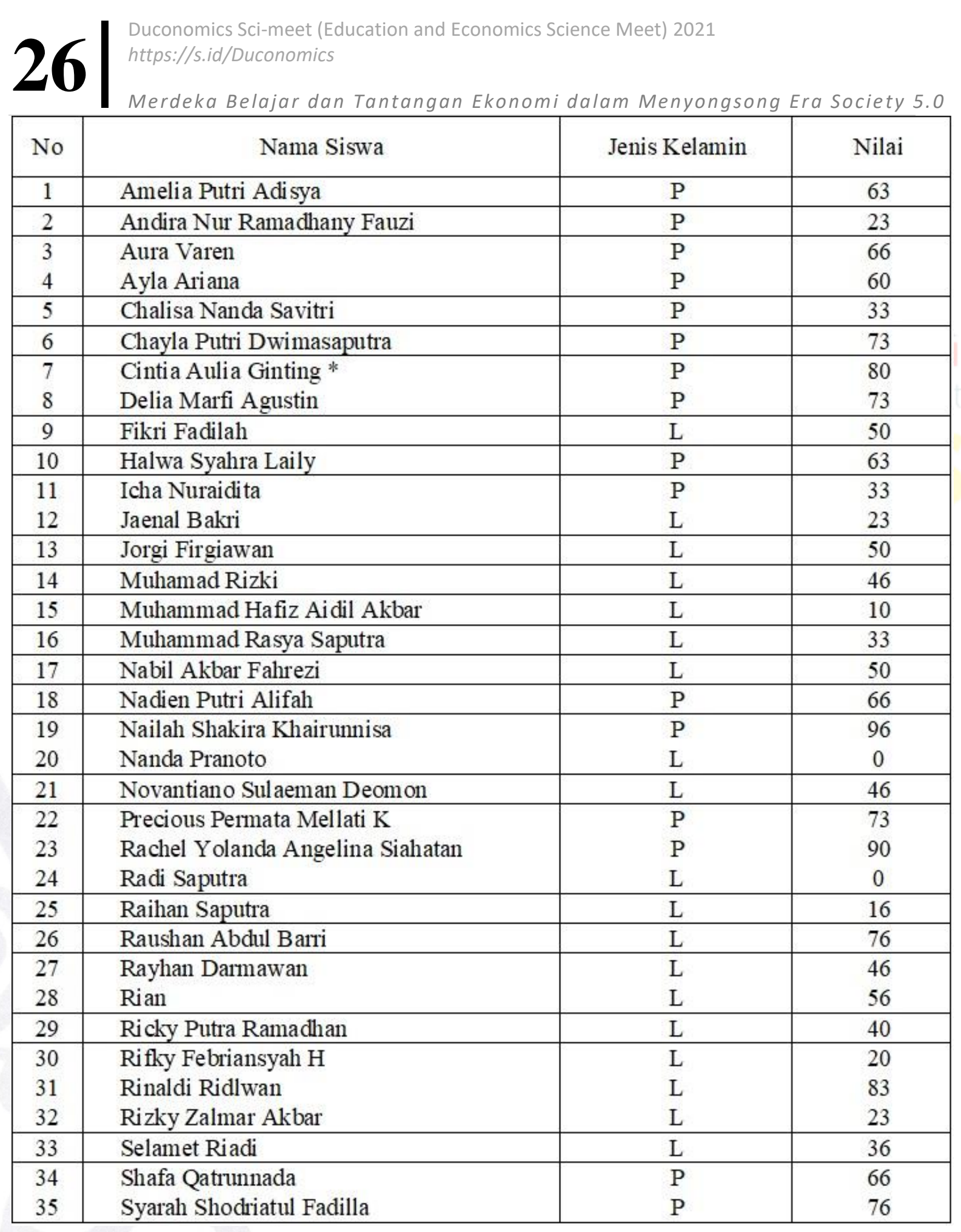

\section{Pembahasan}

Berdasarkan hasil tes kemampuan pemahaman konsep materi segiempat di atas menurut Arikunto (2010) menggunakan kategorisasi dibuat menjadi tiga tingkat, yaitu tinggi, sedang, dan rendah. di mana siswa pada ketegori tinggi yang memperoleh nilai lebih dan nilai rata-rata yang dijumlahkan dengan standar deviasi. Siswa pada kategori rendah yang memperoleh nilai kurang dari selisih dari nilai rata-rata dengan standar deviasi. Sedangkan siswa pada kategori sedang yang memperoleh nilai yang ada diantara nilai kategori tinggi dan rendah. 
Duconomics Sci-meet Vol. 1

Juli, 2021

https://www.doi.org/10.37010/duconomics.v1

Tabel 4. Kategori Kemampuan Pemahaman Konsep

\begin{tabular}{|c|c|c|c|}
\hline Kategori & Kriteria Nilai & $\begin{array}{c}\text { Jumlah } \\
\text { Siswa }\end{array}$ & Hasil dalam persentase \\
\hline Tinggi & $\mathrm{X}>75.05$ & 6 & $17.14 \%$ \\
Sedang & $24.25>\mathrm{X}>75.05$ & 22 & $62.86 \%$ \\
Rendah & $\mathrm{X}<24.25$ & 7 & $20 \%$ \\
\hline
\end{tabular}

Berdasarkan data pada tabel analisis data kemampuan pemahaman konsep pada bangun datar segiempat, dapat disimpulkan bahwa siswa yang berkategori tinggi sebanyak 6 siswa dengan persentase $17.14 \%$, siswa yang berkategori sedang sebanyak 22 siswa dengan persentase $62.86 \%$ sedangkan siswa yang berkategori rendah sebanyak 7 siswa dengan persentase $20 \%$. Jadi dominan kemampuan pemahaman konsep siswa pada bangun datar segiempat pada siswa kelas VII di SMP Negeri 39 Bekasi adalah 62.86\% dengan kategori sedang.

Setelah mengetahui kemampuan peserta didik, peneliti menentukan subjek penelitian. Subjek yang dipilih sebanyak tiga siswa dari masing- masing kemampuan, yaitu tiga subjek untuk kemampuan tinggi, tiga subjek untuk kemampuan sedang, dan tiga subjek untuk kemampuan rendah. Diperoleh hasil seperti tabel berikut:

Tabel 5. Hasil Pemilihan Subjek

\begin{tabular}{|ccc|c|}
\hline No. & Inisial Peserta Didik & $\begin{array}{c}\text { Pengelompokan } \\
\text { Kemampuan }\end{array}$ & $\begin{array}{c}\text { Kode } \\
\text { Subjek }\end{array}$ \\
\hline 1. & RYA & Tinggi & T-1 \\
2. & CAG & Tinggi & T-2 \\
\hline 3. & NSK & Tinggi & T-3 \\
\hline 4. & SQ & Sedang & S-1 \\
\hline 5. & CPD & Sedang & S-2 \\
6. & PPM & Sedang & S-3 \\
\hline 7. & MRS & Rendah & R-1 \\
\hline 8. & ANR & Rendah & R-2 \\
\hline 9. & RZA & Rendah & R-3
\end{tabular}

Data tersebut akan menjadi tolak ukur untuk menyimpulkan bagaimana kemampuan pemahaman konsep matematika subjek penelitian tentang bangun datar segiempat. Kemudian nantinya akan dilakukan pengecekan dengan hasil wawancara terhadap subjek penelitian, teknik pengecekan ini disebut juga teknik triangulasi. Aspek yang diukur untuk mendeskripsikan kemampuan pemahaman konsep matematika, yaitu meliputi:

1. Menyatakan ulang konsep

2. Memberi contoh dari konsep yang telah dipelajari

3. Mengaitkan berbagai konsep yang telah dipelajari

Dari tiga subjek pada masing-masing kelompok tersebut peneliti akan memaparkan hasil tes subjek pada tiap kelompok, siswa dengan kode subjek T-1, T-2 dan T-3 pada kelompok kemampuan tinggi, siswa dengan kode subjek S-1, S-2 dan S-3 pada kelompok kemampuan sedang, dan siswa dengan kode subjek R-1, R-2 dan R-3 pada kelompok kemampuan rendah. Data dalam penelitian ini adalah hasil tes tertulis dan hasil wawancara terhadap subjek penelitian yang telah ditentukan.

Berikut ini adalah hasil analisis kemampuan pemahaman konsep matematika yang ditinjau dari pengelompokan kemampuan mulai dari kemampuan tinggi, kemampuan sedang, 


\section{8}

Merdeka Belajar dan Tantangan Ekonomi dalam Menyongsong Era Society 5.0 dan kemampuan rendah. Berikut ini tabel persentase siswa dalam kemampuan pemahaman konsep matematika berdasarkan tingkatan:

Tabel 6. Persentase Siswa Dalam Kemampuan Pemahaman Konsep Matematika

\begin{tabular}{|c|c|c|c|c|c|c|c|c|c|c|}
\hline \multirow{3}{*}{ No } & \multirow{3}{*}{ Indikator } & \multicolumn{9}{|c|}{ Kemampuan Pemahaman Konsep } \\
\hline & & \multicolumn{3}{|c|}{ Tinggi } & \multicolumn{3}{|c|}{ Sedang } & \multicolumn{3}{|c|}{ Rendah } \\
\hline & & S-1 & $\mathrm{S}-2$ & S-3 & S-1 & S-2 & S-3 & S-1 & S-2 & S-3 \\
\hline 1 & $\begin{array}{l}\text { Menyatakan ulang } \\
\text { konsep }\end{array}$ & $100 \%$ & $90 \%$ & $100 \%$ & $50 \%$ & $100 \%$ & $40 \%$ & $50 \%$ & $0 \%$ & $0 \%$ \\
\hline 2 & $\begin{array}{l}\text { Memberi contoh dari } \\
\text { konsep yang telah } \\
\text { dipelajari }\end{array}$ & $90 \%$ & $80 \%$ & $100 \%$ & $50 \%$ & $70 \%$ & $80 \%$ & $20 \%$ & $70 \%$ & $50 \%$ \\
\hline 3 & $\begin{array}{l}\text { Mengaitkan berbagai } \\
\text { konsep yang telah } \\
\text { dipelajari }\end{array}$ & $80 \%$ & $70 \%$ & $90 \%$ & $100 \%$ & $50 \%$ & $100 \%$ & $30 \%$ & $0 \%$ & $20 \%$ \\
\hline
\end{tabular}

S-1: Siswa 1

S-2: Siswa 2

S-3: Siswa 3

Berdasarkan pembahasan di atas, kemampuan pemahaman konsep matematika subjek dengan pengelompokan kemampuan tinggi dapat dikategorikan baik karena mampu menjawab soal dengan baik di perkuat oleh hasil persentase indikatornya. Kemampuan pemahaman konsep matematika subjek dengan pengelompokan kemampuan sedang dapat dikategorikan kurang baik. Hal tersebut dikarenakan siswa dengan pengelompokan kemampuan rendah hanya dapat memahami masalah atau soal dan kurang teliti untuk menjawab soalnya. Siswa dengan pengelompokan kemampuan rendah juga tidak dapat membuat model matematika dalam merencanakan pemahaman konsep matematika. Sehingga dalam melaksanakan rencana pemahaman konsep siswa mengerjakannya dengan model matematika terlebih dahulu sebisanya bahkan ada beberapa yang tidak menjelaskan apa yang diketahui dan ditanya dalam soal tersebut. Selain itu, siswa belum dapat memeriksa kembali atau mengecek jawaban yang didapatkan.

Dari penjelasan tersebut, sebaiknya guru dalam melakukan pembelajaran selalu mengingatkan siswa agar lebih teliti dalam menuliskan apa yang diketahui dan ditanyakan. Selain itu guru juga harus mengingatkan siswa untuk membuat model matematika sebelum melaksanakan rencana untuk menyelesaikan soal. Kemudian guru juga harus membimbing siswa untuk selalu membuat kesimpulan yang benar di akhir penyelesaian masalah matematika dengan cara selalu mengingatkan siswa saat pembelajaran dan jika jawaban dan konsep yang dibuat peserta didik masih kurang tepat, guru memberikan koreksi dan bersamasama dengan siswa membuat kesimpulan yang benar dan membiasakan memeriksa kembali atau mengecek jawaban yang didapatkan.

\section{PENUTUP}

Berdasarkan hasil penelitian dan pembahasan yang telah dijelaskan pada Bab IV di atas, dapat disimpulkan bahwa siswa yang memiliki kemampuan tinggi, sedang dan rendah memiliki perbedaan kemampuan memahami soal pada indikator pemahaman konsep matematika. Pertama, pada tahap memahami masalah siswa mampu menginterpretasikan masalah yang diberikan oleh peneliti. Selanjutnya pada tahap memberikan contoh dari konsep yang telah dipelajari, siswa sering kali salah membedakan mana yang bangun datar persegi

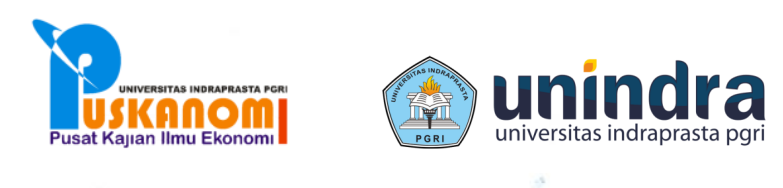


Duconomics Sci-meet Vol. 1

Juli, 2021

https://www.doi.org/10.37010/duconomics.v1

dengan bangun datar persegi panjang dan siswa masih belum hafal nama-nama bangun datar segiempat jadi membuat siswa bingung jika ada gambar bangun datar segiempat ditanyakan bangun apakah yang terdapat pada soal tersebut. Kemudian pada tahap mengaitkan berbagai konsep yang telah dipelajari, siswa masih banyak yang belum paham akan indikator pemahaman konsep ini karena siswa masih bingung rumusnya dan penyelesaian nya seperti apa. Oleh karena itu, di indikator ini siswa pemahaman konsepnya masih rendah karena masih banyak yang belum mengerti.

\section{DAFTAR PUSTAKA}

Semua referensi yang dikutip dalam tubuh artikel wajib dituliskan dalam bagian daftar pustaka dan ditulis dalam 1 spasi secara alfabet, serta menggunakan standar penulisan American Psycological Association (APA). Berikut adalah contoh penulisan daftar pustaka:

Note: Tidak perlu dipisahkan referensi berbentuk buku, jurnal, dan lain sebagainya. Berikut penampakan isi daftar pustaka.

Hamzah. B. 2010. Perencanaan Pembelajaran. Jakarta: Bumi Aksara.

Oktiana Dwi Putra Herawati, dkk, "Pengaruh Pembelajaran Problem Posing Terhadap Kemampuan Pemahaman Konsep Matematika Siswa Kelas XI IPA SMA Negeri 6 Palembang", Jurnal Pendidikan Matematika, Vol.4 No.1 (2010), hlm. 71

Undang-Undang RI No, 20 Tahun 2003 Tentang Sistem Pendidikan Nasional (SISDIKNAS), (Bandung: Citra Umbara, 2008), hal. 3

Syaiful Sagala. 2011. Konsep dan Makna Pembelajaran. Bandung: AlfabetaUno.

Permendikbud Nomor 58 Tahun 2014 tentang Kerangka Dasar dan Struktur Kurikulum Sekolah Menengah Pertama/Madrasah Tsanawiyah, (Jakarta: Kemendikbud, 2014).

Hadi, Sutarto \& Kasum, M. U, "Pemahaman Konsep Matematika Siswa SMP Melalui Penerapan Model Pembelajaran Kooperatif Tipe Memeriksa Berpasangan (Pair Checks)", EDU-MAT Jurnal Pendidikan Matematika, Vol. 3 No. 1 (2015), Hal 59 66.

Sari, A M 2013. Analisis Pemahaman Konsep Matematika Siswa Dengan Model Pembelajaran Problem Based Learning Pada Pokok Bahasan Segitiga Studi Deskriptif di Kelas VII SMP Negeri 2 Plered Kab. Cirebon. Cirebon: Fakultas Tarbiyah IAIN Syekh Nurjati Cirebon.

Aunurrahman. 2013. Belajar dan Pembelajaran. Bandung: Alfabeta

Dimyati dan Mudjiono. 2009. Belajar dan Pembelajaran. Jakarta: Rineka Cipta.

Moleong, Lexy J. 2010. Metodologi penelitian kualitatif. Bandung: Remaja Rosdakarya.

Sugiyono. 2010. Metode Penelitian Pendidikan Pendekatan Kuantitatif, kualitatif, dan R\&D. Bandung: Alfabeta

Moh Nazir. 2003. Metode Penelitian. Jakarta : Ghalia Indonesia.

Tatag Yuli Eko Siswono. 2010. Penelitian Pendidikan Matematika. Surabaya: Unesa University Press.

Wiersma, William. 1986. Research Methods In Education: An Introduction. Massachusetts: Allyn and Bacon, Inc. 
Merdeka Belajar dan Tantangan Ekonomi dalam Menyongsong Era Society 5.0

Sutriningsih, Naning, "Penyebab Siswa Underachiever Dalam Pembelajaran Matematika". Jurnal Edumath, Vol. 3 No. 2 (2017), hlm. 148-154.

Zulkardi dan Ratu Ilma, "Pengembangan Blog Support untuk Membantu Siswa dan Guru Matematika Indonesia Belajar Pendidikan Matematika Realistik Indonesia (PMRI)”, JIPPBalitbang (2010).

Permendikbud Nomor 58 Tahun 2014 tentang Kerangka Dasar dan Struktur Kurikulum Sekolah Menengah Pertama/Madrasah Tsanawiyah. Jakarta: Kemendikbud.2014.

Arnidha, Yunni, "Analisis pemahaman konsep Subjek sekolah dasar dalam menyelesaikan bangun datar", Jurnal Review JPGMI Vol. 3 No. 1 (2017), hlm. 53-61.

Arikunto, Suharsimi. 2010. Prosedur Penelitian Suatu pendekatan Praktek. Jakarta: Rineka Cipta.

Annajmi, "Peningkatan Kemampuan Pemahaman Konsep Matematik Siswa SMP melalui penemuan terbimbing berbantu software geogebra". MES (Journal of Mathematics Education and Science) Vol. 2 No. 1 (2016), hlm.1-9.

Martunis, dkk, "Meningkatkan Kemampuan Pemahaman dan Komunikasi Matematis Siswa Sekolah Menengah Atas melalui Model Pembelajaran Generatif. Jurnal Didaktik Matematika”, ISSN: 2355-4185 Vol 1 No 2 (2014), hlm 75-84.

Afrilianto, M, "Peningkatan Pemahaman Konsep dan Kompetensi Strategis Matematis Siswa SMP dengan Pendekatan Metaphorical Thinking”. Jurnal ilmiah program studi matematika STKIP Siliwangi Bandung Vol. 1 No. 2 (2012).

Sari, P. 2011. Pengaruh Contextual Teaching and Learning (CTL) Terhadap Kemampuan Pemahaman Konsep Matematika Siswa SMA Taruna Indonesia Palembang. Skripsi Universitas PGRI Palembang: Tidak dipublikasikan

Kilpatrick; J., Swafford, J., \& Findell, B. (Eds.). (2001). Adding it Up: Helping Children Learn Mathematics. Washington, DC: National Academy Press.

Rusyda , N.A., dan Dwi, S.S, Pengaruh Penerapan Model Contextual teaching and Learnin terhadap Kemampuan Pemahaman Konsep Matematis siswa SMP Pada Materi Garis dan sudut. JNPM Vol. 1 No. 1 (2017), hlm. 150-162.

Yuli Eko Siswono, Tatag. 2010. Pembelajaran Matematika Berbasis Pengajuan dan Pemecahan Masalah (JUCAMA) untuk Meningkatkan Kemampuan Berpikir Kreatif Siswa. Makalah Seminar. Surabaya. 